\title{
Epicutaneous Immunization with TNP-Ig and Zymosan Induces TCRa $\beta+C D 4+$ Contrasuppressor Cells That Reverse Skin-Induced Suppression via IL-17A
}

\author{
Monika Majewska-Szczepanik ${ }^{a}$ Anna Strzepa $^{a}$ Katarzyna Marcińska ${ }^{a}$ Li Wen $^{b}$ \\ Marian Szczepanik ${ }^{\mathrm{a}}$ \\ ${ }^{a}$ Department of Medical Biology, Faculty of Health Sciences, Jagiellonian University College of Medicine, Krakow, Poland; \\ ${ }^{b}$ Department of Internal Medicine, Section of Endocrinology, Yale University School of Medicine, New Haven, Conn., USA
}

\author{
Key Words \\ Contact hypersensitivity · Epicutaneous immunization . \\ Contrasuppression
}

\begin{abstract}
Background: Our previous work showed that epicutaneous (EC) immunization with protein antigen e.g. TNP-conjugated mouse immunoglobulin (TNP-lg) in the form of a patch prior to hapten sensitization inhibits Th1-mediated contact hypersensitivity $(\mathrm{CHS})$ in mice. We also found that suppression of $\mathrm{CHS}$ was mediated by TCRa $\beta+C D 4+C D 8+T$ suppressor cells producing TGF- $\beta$. The aim of this study was to investigate the role of innate immunity in the suppression of $\mathrm{CHS}$. Methods: Mice were immunized by applying gauze patches containing protein antigen alone or in the presence of zymosan, and were then tested for the CHS response. Adoptive cell transfer experiments were used to study the mechanisms involved in the reversal of skin-induced suppression. The influence of $\mathrm{EC}$ immunization on cytokine production by lymph node cells was measured by ELISA. Results: We found that EC immunization with TNP-Ig and zymosan before trinitrophenyl chloride sensitization reverses skin-induced suppression, demonstrated in vivo and in vitro. The reversal of skin-induced suppression was transferable by antigen-specific TCRa $\beta+C D 4+T$ contrasuppressor cells. Furthermore, we showed that the contrasuppression was IL-17A-depen-
\end{abstract}

dent and TLR2- and MyD88-independent. Conclusions: Our work strongly suggests that $\mathrm{EC}$ immunization with protein antigen and zymosan reverses skin-induced suppression and that this approach may be a potential tool to increase the immunogenicity of weakly immunogenic antigens.

(c) 2014 S. Karger AG, Basel

\section{Introduction}

The skin forms an effective barrier between the host and the environment, protects against chemical and physical aggression and prevents the invasion of pathogens. The concept that the skin is a unique and important immune organ is well accepted. It has been known for a long time that immunization via the skin leads to a strong immune response, e.g. contact hypersensitivity (CHS). While the skin is considered an organ where immune responses are easily induced [1], little attention has been given to skin-induced suppression.

Our previous work showed that epicutaneous (EC) immunization of mice with different protein antigens applied on the skin in the form of a gauze patch or cream emulsion induces a state of subsequent tolerance that inhibits both Th1- and Tc1-mediated CHS [2-5]. Further study showed that maneuvering EC immunization with protein antigens also suppresses NK cell-dependent CHS

\section{KARGER}

E-Mail karger@karger.com

www.karger.com/iaa
(C) 2014 S. Karger AG, Basel

$1018-2438 / 14 / 1642-0122 \$ 39.50 / 0$
Correspondence to: Prof. Marian Szczepanik

Department of Medical Biology, Jagiellonian University College of Medicine ul. Kopernika 7

PL-31-034 Krakow (Poland)

E-Mail mmszczep@cyf-kr.edu.pl 
[6]. This was also found in an animal model of multiple sclerosis, experimental autoimmune encephalomyelitis, where EC immunization with myelin basic protein reduced disease severity and decreased disease incidence $[7,8]$.

Our findings are in line with the study that used a myelin basic protein-specific TCR transgenic mouse model, in which EC immunization with myelin basic protein peptides induced $\mathrm{T}$ suppressor cells; this protects mice from developing experimental autoimmune encephalomyelitis [9]. Furthermore, using an allogeneic skin graft experimental model, we showed that EC immunization with a protein antigen delays graft rejection [10]. It is interesting that EC immunization with the protein antigen TNP-conjugated mouse immunoglobulin (TNP-Ig) can also alleviate TNBS-induced colitis in mice [11]. Finally, study has shown that maneuvering EC immunization inhibits both the onset and progression of collagen-induced arthritis [12]. In summary, EC immunization can effectively suppress undesired immune responses including autoimmunity and graft rejection.

It has been described that EC induced suppression is antigen-nonspecific and transferable with TCR $\alpha \beta+\mathrm{CD} 4+$ $\mathrm{CD} 8+\mathrm{T}$ suppressor $(\mathrm{Ts})$ cells $[2,8]$ or $\mathrm{TCR} \alpha \beta+\mathrm{CD} 4+$ CD25+ FoxP3+ T regulatory cells [4] in Th1- and Tc1mediated immune responses, respectively.

The skin constantly interacts with the environment and many commensal bacteria can be found on the skin. We found that EC induced antigen-nonspecific suppression can be reversed by crude bacterial lysates as well by purified TLR2, TLR3, TLR4 and TLR9 ligands [13]. Further experiments showed that EC immunization with TLR4 ligand LPS induces regulatory cells that reverse skin-induced suppression. These regulatory cells, designated as contrasuppressor $\mathrm{T}$ (Tcs) cells, belong to the population of TCR $\alpha \beta+\mathrm{CD} 4+$ lymphocytes that are antigen-specific. Induction of these Tcs cells was TLR4- and MyD88-dependent [14] and the contrasuppression was IFN- $\gamma$ - and IL-12-dependent and IL-6-independent.

Zymosan is a major cell wall component of Saccharomyces cerevisiae, a much-used yeast in daily life and in industry. Zymosan is also a ligand for TLR2. Since the skin continually interacts with the environment, we hypothesized that zymosan may play a role in EC induced contrasuppression. To test our hypothesis, we used an experimental model of EC immunization with TNP-Ig in the presence or absence of zymosan. Our results showed that EC immunization with TNP-Ig and zymosan induces regulatory cells: Tcs cells that can reverse skin-induced suppression. These contrasuppressor cells belong to the population of TCR $\alpha \beta+\mathrm{CD} 4+$ lymphocytes. We also showed that the observed reversal of skin-induced suppression was antigen-specific and IL-17A-dependent but TLR2- and MyD88-independent.

\section{Material and Methods}

Mice

$\mathrm{CBA} / \mathrm{J}\left(\mathrm{H}-2^{\mathrm{k}}\right)$ mice from the breeding unit of the Department of Medical Biology, Jagiellonian University College of Medicine were used. In some experiments, CBA/J $\left(\mathrm{H}-2^{\mathrm{k}}\right)$ and $\mathrm{C} 57 \mathrm{Bl} / 6(\mathrm{H}-$ $2^{\mathrm{b}}$ ) mice purchased from The Jackson Laboratory (Bar Harbor, Me., USA) were also used. TLR2-/-, MyD88-/- and IL-17A-/mice on $\mathrm{C} 57 \mathrm{Bl} / 6$ background were generated as previously reported [15] and were bred at the Yale University School of Medicine. All the mice used in this study were kept in SPF conditions and used at 6-10 weeks of age in groups of 3-9. All the experiments were conducted according to the guidelines of both the Jagiellonian University College of Medicine and Yale University.

\section{Reagents}

Trinitrophenyl chloride (TNP-Cl) (Chemica Alta, Edmonton, Canada), 4-ethoxymethylene-2-phenyl-2-oxazolin-5-one (OX), Evans blue, formamid, hexadecyltrimethylammonium bromide, o-dianisidine dihydrochloride and hydrogen peroxide were obtained from Sigma-Aldrich (St. Louis, Mo., USA). Protein A was from Pharmacia Fine Chemicals (Piscataway, N.J., USA) and Sepaharose 4 Fast Flow was obtained from Pfizer-Pharmacia (LKB Biotechnology AB, Uppsala, Sweden). Low-tox rabbit complement (RC) was from Pel-Freeze Biologicals (Brown Deer, Wisc.), LPS from Escherichia coli 026:B6, zymosan from S. cerevisiae and curdlan from Alcaligenes faecalis were obtained from Sigma-Aldrich. Horseradish peroxidase streptavidin was obtained from Vector Laboratories (Burlingame, Calif., USA). Mouse immunoglobulins were prepared from CBA/J mouse sera and conjugated with TNP hapten $[16,17]$. A single preparation with a level of substitution of 40 TNP per immunoglobulin molecule $\left(\mathrm{TNP}_{40}-\mathrm{Ig}\right)$ was used throughout the study. Mouse immunoglobulins were conjugated with OX $\left(\mathrm{OX}_{20}-\mathrm{Ig}\right)$, as described by Askenase and Asherson [18]. In addition, a mouse Pan T Cell Isolation Kit II and CD4 MicroBeads were purchased from Miltenyi Biotec (Bergisch Gladbach, Germany).

\section{Monoclonal Antibodies and Hybridomas}

The following hybridomas were cultured: anti-TCR $\beta$ clone (H57-597) from Dr. R. Kubo, Cytel Inc., and anti-CD4 (clone TIB 207) and anti-CD8 (clone TIB 105.3) from the late Dr. C.A. Janeway, Jr., Yale University, New Haven, Conn. The culture supernatants were then purified on protein A as described previously [19].

\section{Sensitization and Elicitation of CHS in vivo}

Mice were sensitized by topical application of $0.15 \mathrm{ml}$ of $5 \%$ TNP-Cl in an acetone-ethanol mixture (1:3) to the shaved abdomen and chest. Control mice were shaved and painted with the acetone-ethanol mixture alone as a sham sensitization. Four days later, the mice were challenged on both sides of the ears with $10 \mu \mathrm{l}$ of $0.4 \%$ TNP-Cl in an olive oil-acetone mixture (1:1). Resulting ear 
thickness was measured prior to testing with a micrometer (Mitutoyo, Tokyo, Japan) by an observer unaware of the experimental groups, and then again at $24 \mathrm{~h}$ after challenge. The background ear thickness $( \pm 20 \mu \mathrm{m}$ at $24 \mathrm{~h}$ ) of littermate sham-sensitized animals that were similarly challenged was subtracted from each experimental group to yield the net ear swelling expressed in $\mu \mathrm{m} \pm \mathrm{SE}$ [2]. Ear swelling was further confirmed by the measurements of ear weight, vascular permeability, myeloperoxidase (MPO) activity and IL-17A concentration in ear extracts.

\section{Vascular Permeability Test}

To assess very early changes in vascular permeability, TNP-Cl immunized or naïve mice were challenged with $10 \mu \mathrm{l}$ of $0.4 \% \mathrm{TNP}$ $\mathrm{Cl}$ and then injected with $1 \%$ Evans blue dye ( $83 \mu \mathrm{g} / \mathrm{g}$ body weight) $23 \mathrm{~h}$ later. They were anesthetized and sacrificed $1 \mathrm{~h}$ after the Evans blue injection. Ears were removed and a 6-mm-diameter punch of the ear was made with a biopsy punch (Frey Products Corp., cat\# BP60). Ear punches were transferred to tubes containing $1 \mathrm{ml}$ of formamid. After 18 -hour incubation at $37^{\circ} \mathrm{C}$, the samples were centrifuged and the optical density of Evans blue in the supernatant was read at $565 \mathrm{~nm}$ against a blank containing formamid [20].

\section{MPO Assay}

Neutrophil infiltration to the inflamed ears was indirectly quantitated using an MPO assay, as described previously [20]. Ears were removed $24 \mathrm{~h}$ after challenge and a 6-mm-diameter punch of the ear was made. Biopsies were also collected from the distal site of the CHS responses and homogenized in $0.5 \%$ hexadecyltrimethylammonium bromide $\mathrm{pH}=6.0$ (50 $\mathrm{mg}$ of tissue/ $\mathrm{ml}$ ). The homogenates were freeze-thawed 3 times and centrifuged at $40,000 \mathrm{~g}$. Aliquots $(0.1 \mathrm{ml})$ were mixed with $2.9 \mathrm{ml}$ phosphate buffer $(\mathrm{pH}=6.0)$ containing $0.167 \mathrm{mg} / \mathrm{ml}$ o-dianisidine dihydrochloride and $5 \times 10^{-4} \% \mathrm{H}_{2} \mathrm{O}_{2}$ and incubated at $25^{\circ} \mathrm{C}$ for $20 \mathrm{~min}$. The absorbance was measured at $460 \mathrm{~nm}$ in $96-$ well, flatbottom plates. MPO activity was expressed in units per protein concentration (U/mg of protein).

\section{in vitro Measurement of IL-17A in CHS Ear Extracts}

To determine the local production of IL-17A in elicited TNP$\mathrm{Cl}$ CHS, mice were immunized with $5 \%$ TNP-Cl or sham-sensitized and challenged with $10 \mu \mathrm{l}$ of $0.4 \%$ TNP-Cl 4 days later. The ears were removed $24 \mathrm{~h}$ after challenge and a 6-mm-diameter punch of the ear was made. Biopsies were collected from the distal site of CHS ear responses. The biopsies were frozen rapidly in liquid $\mathrm{N}_{2}$ and were subsequently thawed and extracted in $300 \mu \mathrm{l}$ cold PBS on ice with a tissue microhomogenizer. The concentration of IL-17A was measured by ELISA with the use of a BD OptEIA set (BD Biosciences, San Diego, Calif., USA).

Epicutaneous Immunization with TNP-Ig and

Pathogen-Associated Molecular Patterns

EC immunization was performed by applying a gauze patch $\left(1 \mathrm{~cm}^{2}\right)$ soaked with a solution containing $100 \mu \mathrm{g}$ TNP-Ig alone or TNP-Ig plus $100 \mu \mathrm{g}$ of zymosan in $100 \mu \mathrm{l}$ PBS to the shaved skin on the mouse dorsum on day 0 . The patch was secured by adhesive tape wrapped around the midsection of the mouse. Control mice were EC immunized with zymosan or PBS alone. The patch was left in place from day 0 until day 4 , when it was replaced by a fresh patch. On day 7, the patches were removed and the mice were actively sensitized with TNP-Cl. An identical procedure was used for
EC immunization with OX-Ig. In some experiments, mice were patched with $100 \mu \mathrm{g}$ TNP-Ig plus $100 \mu \mathrm{g}$ of curdlan or $100 \mu \mathrm{g}$ of curdlan alone prior to TNP-Cl sensitization.

\section{Adoptive Cell Transfer of CHS and Cell-Mixing Assay to}

Evaluate Contrasuppression ('Transfer out' Protocol)

Donors of CHS effector immune cells were sensitized with 5\% TNP-Cl. CHS effector immune cells from auxiliary and inguinal lymph nodes (ALN) and spleens were harvested on day 4 . After incubation for $30 \mathrm{~min}$ at $37^{\circ} \mathrm{C}$ in RPMI 1640 medium, immune cells were washed and injected $\left(7 \times 10^{7} /\right.$ mouse $)$ i.v. into naïve syngeneic recipients (positive control). For cotransfer, ALN cells, isolated from mice EC immunized with TNP-Ig and harvested on day 7 [14], were used as the source of Ts cells. CHS effector immune cells $\left(7 \times 10^{7}\right)$ from the TNP-Cl-sensitized donors were cotransferred with $5 \times 10^{7}$ Ts cells i.v. into naïve recipients (suppression control). To test if EC immunization with TNP-Ig and zymosan induces regulatory cells that could reverse skin-induced suppression, we 'generated' Tcs cells, which were harvested from mice after EC immunization with TNP-Ig and zymosan on day 7. ALN cells from these mice were used as Tcs cells, and $7 \times 10^{7}$ of the CHS effector immune cells from the TNP-Cl-sensitized donors were mixed with $5 \times 10^{7}$ Tcs cells. The cell mix was then incubated for $30 \mathrm{~min}$ at $37^{\circ} \mathrm{C}$ with $5 \times 10^{7}$ lymphoid cells from mice that were EC immunized with TNP-Ig alone and harvested on day 7 (Ts cells). The final mixture of 3 types of cells was transferred i.v. into naïve recipients (contrasuppression control). Recipients were subsequently ear-challenged with TNP-Cl within 30 min of cell transfer and were tested for CHS after $24 \mathrm{~h}$, as described above.

\section{Transfer of Regulatory Cells into EC Tolerized or}

Contrasuppressed Mice ('Transfer in' Protocol)

To test whether EC induced Ts or Tcs cells could interfere with the active induction of contrasuppression or suppression, respectively, we developed a 'transfer in' protocol. Recipients were i.v. injected with $5 \times 10^{7} \mathrm{Tcs}$ or Ts cells $2 \mathrm{~h}$ before patching with TNPIg or TNP-Ig plus zymosan, respectively. The suppression control mice were not transferred with any cells before EC immunization with TNP-Ig. Mice that were EC immunized with TNP-Ig and zymosan but did not receive cell transfer were considered as contrasuppression controls.

One week after EC immunization, all groups underwent sensitization with 5\% TNP-Cl. The positive-control mice (patched with PBS) were sensitized with TNP-Cl. Four days later, all animals were challenged and tested for $\mathrm{CHS}$.

\section{Phenotype of Contrasuppressor Cells}

To determine the phenotype of skin-induced contrasuppressor cells in vivo, $5 \times 10^{7}$ cells isolated from mice EC immunized with TNP-Ig plus zymosan were incubated in PBS on ice with purified anti-TCR $\beta$ or anti-CD4 or anti-CD8 monoclonal antibodies (mAbs; $1 \mu \mathrm{g} \mathrm{mAb} / 10^{6}$ cells) or with PBS alone for $45 \mathrm{~min}$. The cells were then washed and incubated with a predetermined dilution of $\mathrm{RC}$ for $60 \mathrm{~min}$ at $37^{\circ} \mathrm{C}$ to lyse the $\mathrm{mAb}$-bound cells. After washing, the cells were resuspended in PBS. The cell equivalents were transferred into syngeneic recipients that were EC immunized with a TNP-Ig patch for 1 week. After removing the patches, the mice were sensitized with TNP-Cl. Mice patched with PBS before TNP$\mathrm{Cl}$ sensitization were used as positive controls. In the contrasuppression control, recipients received Tcs cells treated with RC 
alone before patching with TNP-Ig and subsequent sensitization with TNP-Cl. The suppressor control group consisted of mice EC immunized with TNP-Ig and painted with TNP-Cl. Four days after sensitization, all mice were challenged and tested for CHS. In addition, in one of the experiments, a pure population of MACSisolated TCR $\alpha \beta+\mathrm{CD} 4+$ lymphocytes was used as Tcs cells.

\section{Reversal of Skin-Induced Suppression in vitro}

$\mathrm{CBA} / \mathrm{J}$ mice were first EC exposed to TNP-Ig alone, TNP-Ig plus zymosan or zymosan alone, as described above. On day ' +7 ' mice were sensitized by topical application of $5 \%$ TNP-Cl. As a positive control, we used mice that were EC treated with PBS alone prior to TNP-Cl sensitization. In some experiments, mice were patched with $100 \mu \mathrm{g}$ TNP-Ig plus $100 \mu \mathrm{g}$ of curdlan or 100 $\mu \mathrm{g}$ of curdlan alone prior to TNP-Cl sensitization. Four days after TNP-Cl immunization, single-cell suspensions of ALN cells were prepared under aseptic conditions and $3 \times 10^{5}$ ALN cells were incubated in U-bottom, 96-well microplates (Falcon, Oxnard, Calif., USA) in triplicate, with 3-fold decreasing dilutions of TNP-Ig starting with $300 \mu \mathrm{g} / \mathrm{ml}$ in $200 \mu \mathrm{l}$ of RPMI 1640 (containing $100 \mathrm{U} / \mathrm{ml}$ penicillin, $100 \mu \mathrm{g} / \mathrm{ml}$ streptomycin, $2 \mathrm{mM} \mathrm{L}$-glutamine, $25 \mathrm{~mm}$ Hepes, $5 \times 10^{-5} \mathrm{M} 2$-mercaptoethanol and $10 \%$ fetal calf serum) for $48 \mathrm{~h}$. The cells were incubated for an additional $18 \mathrm{~h}$ once $0.5 \mu \mathrm{Ci} /$ well of $\left[{ }^{3} \mathrm{H}\right]$-thymidine had been added. Cell proliferation was measured by $\left[{ }^{3} \mathrm{H}\right]$-thymidine incorporation [14]. Results are presented as mean c.p.m. \pm SD. Background c.p.m. (cells cultured without antigen) were subtracted from all tested groups.

\section{Cytokine (IFN- $\gamma$ and IL-17A) immunoassays}

Mice were EC immunized with TNP-Ig alone, TNP-Ig and zymosan or zymosan alone as described above. Mice EC treated with PBS were used as controls. ALN cells were collected on day 7 from the 4 groups of mice and cultured $\left(3 \times 10^{6}\right.$ cells $)$ in $1 \mathrm{ml}$ of RPMI 1640 medium supplemented with $10 \%$ FCS in the presence of 100 $\mu \mathrm{g} / \mathrm{ml} \mathrm{TNP}_{40}$-Ig. Cells were distributed in triplicate in flat-bottom, 24-well Falcon plates. The culture supernatants were collected after $48 \mathrm{~h}$ and tested for cytokine production using BD OptEIA sets [14].

\section{Statistical Analysis}

The data are shown on graphs and as mean \pm SE. ANOVA, followed by the Tukey post test, was used for multiple comparisons. $\mathrm{p}<0.05$ was considered statistically significant.

\section{Results}

Skin-Induced Suppression Is Reversed by EC Application of TNP-Ig Together with Zymosan

To test the role of environmental influence on skininduced suppression, we studied zymosan, which is a major component of a much-used yeast. We EC immunized CBA/J mice with $100 \mu \mathrm{g}$ of TNP-Ig, TNP-Ig plus $100 \mu \mathrm{g}$ zymosan, zymosan alone or PBS, as described in Materials and Methods. The mice were further sensitized with 5\% TNP-Cl on day 7 and CHS was tested 4 days after sensitization. Figure 1 illustrates the experimental procedure. Figure 2a shows that mice exposed to TNP-Ig prior to TNP-Cl sensitization developed significantly decreased CHS (group B vs. A). However, EC exposure to TNP-Ig plus zymosan before CHS induction reversed skin-induced suppression in vivo (group C vs. B). Patching with zymosan alone prior to TNP-Cl sensitization did not significantly affect CHS (group D vs. A). To confirm the results, we measured the vascular permeability of the above 4 groups of mice in a separate set of experiments. As shown in figure $2 \mathrm{~b}$, vascular permeability was significantly reduced by TNP-Ig and this reduction was reversed in the presence of zymosan. The reversal of skin-induced suppression was further confirmed by 3 additional tests including the measurement of ear weight (fig. 2c), MPO activity (fig. 2d) and IL-17A production in the ear extracts (fig. 2e). Finally, the in vivo observations were fully confirmed by proliferation assay in vitro (fig. 3).

\section{EC Immunization with Antigen and Zymosan Induces} Tcs Cells

Our results showed that zymosan could reverse immune suppression induced by EC immunization with TNP-Ig. To investigate the mechanism of this suppression reversal, in particular which cell type is involved in this contrasuppression, we used 'a transfer out' protocol using 3 cell types: TNP-specific CHS effector cells, TNPIg EC immunization-derived suppressor cells and TNPIg with zymosan-derived contrasuppressor cells. As shown in figure $4 \mathrm{a}, \mathrm{CHS}$ can be induced in naïve recipients by transferring effector cells (group A), and the cotransfer of effector cells and Ts cells resulted in the inhibition of CHS (group B). Importantly, the transfer of all 3 cell types reversed the inhibition (group C), which suggests that zymosan promoted the Tcs cells. However, transferring the Tcs cells alone into naïve recipients that were subsequently challenged did not transfer CHS (group D). Similarly, in a nontransfer experiment, mice were EC immunized with TNP-Ig plus zymosan, and the subsequent challenge with TNP-Cl on the ears did not develop CHS (data not shown). Further, employing 'transfer in' protocol, we found that Tcs cells blocked EC induced suppression when transferred into the mice just before immunization via skin patching with TNP-Ig alone (fig. 4b; group E vs. B). Moreover, the transfer of Ts cells from donors EC immunized with TNP-Ig did not disturb the induction of contrasuppression when transferred just before EC immunization with TNP-Ig plus zymosan (fig. $4 \mathrm{~b}$; group D vs. B). We also showed that the induction of Tcs cells by zymosan 
Fig. 1. $\mathrm{CBA} / \mathrm{J}$ mice were patched with $\mathrm{PBS}$ or $100 \mu \mathrm{g}$ TNP-Ig alone or TNP-Ig plus 100 $\mu \mathrm{g}$ of zymosan or zymosan alone on days 0 and 4. On day 7, patches were removed and mice were actively sensitized with 5\% TNP$\mathrm{Cl}$. Four days later, the animals were challenged on the ears with $0.4 \%$ TNP-Cl and then tested for CHS $24 \mathrm{~h}$ later, as described in Materials and Methods.

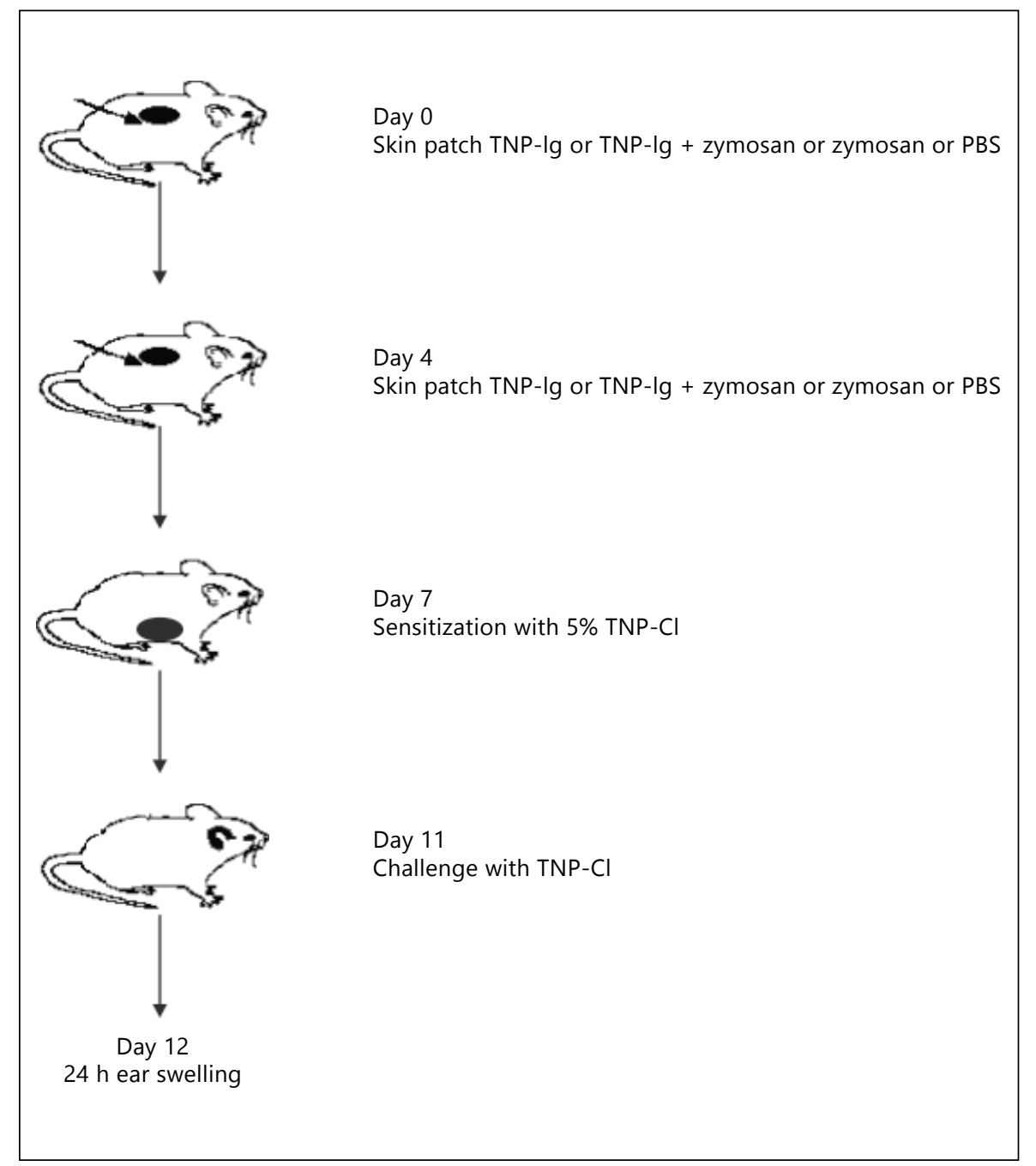

Fig. 2. a Reversal of skin-induced suppression in vivo. CBA/J mice were EC exposed to PBS (group A) or TNP-Ig (group B) or TNPIg plus zymosan (group C) or zymosan alone (group D) prior to TNP-Cl sensitization. Four days later, a CHS response was elicited and then tested $24 \mathrm{~h}$ later. Results are shown as mean \pm SE $(n=18)$. $* * * \mathrm{p} \leq 0.001$. b EC immunization with TNP-Ig and zymosan reverses decreased vascular permeability. CBA/J mice were patched with PBS (group A) or TNP-Ig (group B) or TNP-Ig plus zymosan (group C) or zymosan alone (group D) prior to TNP-Cl sensitization, challenge and then injection of $1 \%$ Evans blue dye. One hour later, the mice were killed and the ear punches were collected. Evans blue dye was extracted and the optical density was read at 565 $\mathrm{nm}$. For details, see Materials and Methods. Results are shown as mean \pm SE $(n=12) .{ }^{* *} \mathrm{p} \leq 0.01,{ }^{* * *} \mathrm{p} \leq 0.001$. c Patching with TNP-Ig and zymosan reversed decreased ear weight when compared to EC tolerized mice. Ears were removed and a punch of the ear was made. The weight of the ear punches was evaluated with the use of an analytical scale, as described in Materials and Meth- ods. Results are shown as mean $\pm \mathrm{SE}(\mathrm{n}=9) .{ }^{*} \mathrm{p} \leq 0.05,{ }^{* * *} \mathrm{p} \leq$ 0.01. d EC immunization with TNP-Ig and zymosan reversed inhibited MPO activity. CBA/J mice were EC treated with PBS (group A) or TNP-Ig (group B) or TNP-Ig plus zymosan (group C) or zymosan alone (group D) prior to TNP-Cl sensitization followed by ear challenge. Ears were removed $24 \mathrm{~h}$ after challenge and punches were collected. Biopsies were homogenized and MPO activity was measured, as described in Materials and Methods. MPO activity was expressed in units per protein concentration $(\mathrm{U} / \mathrm{mg}$ of protein). Results are shown as mean $\pm \mathrm{SE}(\mathrm{n}=6) .{ }^{* *} \mathrm{p} \leq 0.01$, $* * * \mathrm{p} \leq 0.001$. e Patching with TNP-Ig and zymosan reversed IL$17 \mathrm{~A}$ production in ear extracts. $\mathrm{CBA} / \mathrm{J}$ mice were $\mathrm{EC}$ treated with PBS (group A) or TNP-Ig (group B) or TNP-Ig and zymosan (group C) or zymosan alone (group D) prior to TNP-Cl sensitization and challenge. Ear punches were collected $24 \mathrm{~h}$ after challenge. Concentration of IL-17A was measured in tissue homogenates by ELISA. Results are shown as mean $\pm \mathrm{SE}(\mathrm{n}=15) .{ }^{*} \mathrm{p} \leq 0.05$. n.s. $=$ Non-significant.

(For figure see next page.) 


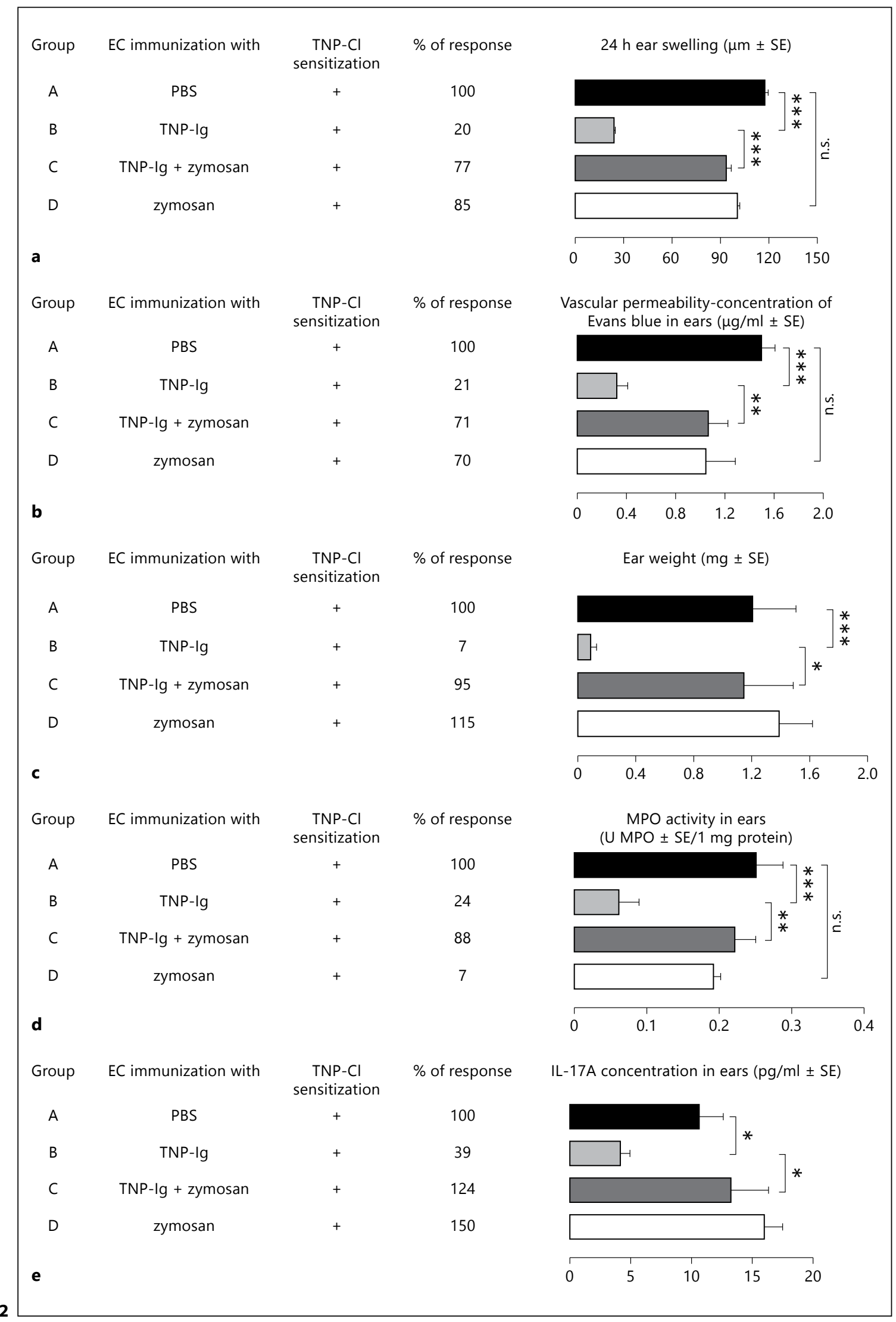


Fig. 3. $\mathrm{CBA} / \mathrm{J}$ mice were patched with $\mathrm{PBS}$ (group A) or TNP-Ig (group B) or TNP-Ig plus zymosan (group C) or zymosan alone (group D) prior to TNP-Cl sensitization. Four days later, inguinal and auxiliary LN were isolated and $3 \times 10^{5}$ ALN cells were cultured in triplicate in the presence of 3-fold dilutions of TNP-Ig for $48 \mathrm{~h}$ prior to the addition of $\left[{ }^{3} \mathrm{H}\right]$-thymidine for an additional $18 \mathrm{~h}$. $\left[{ }^{3} \mathrm{H}\right]$-thymidine incorporation was determined by beta liquid scintillation counting. Results are presented as mean $\pm \mathrm{SE}(\mathrm{n}=3) .{ }^{* *} \mathrm{p} \leq 0.01,{ }^{* * *} \mathrm{p} \leq 0.001$. n.s. $=$ Non-significant.

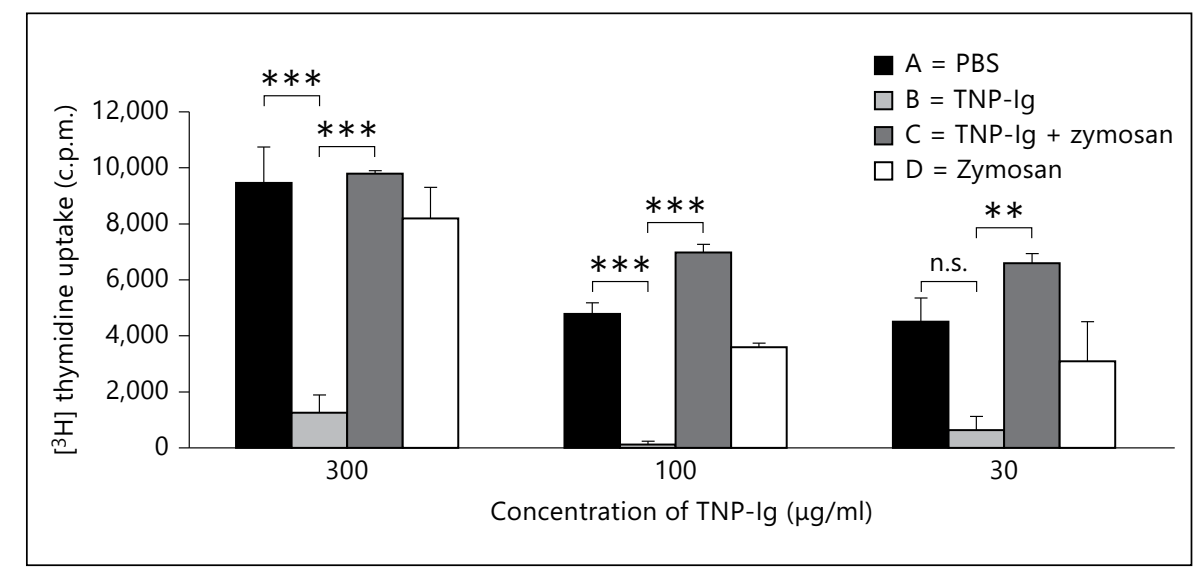

was antigen-dependent, as zymosan without TNP-Ig antigen could not induce Tcs cells (fig. 4c; group D vs. C). Our data strongly suggest that EC treatment with protein antigen and zymosan induces regulatory Tcs cells that counterregulate the suppression of Ts cells on CHS effector cells.

\section{EC Induced Tcs Cells Belong to the Population of TCR $\alpha \beta+C D 4+$ Lymphocytes}

To determine the phenotype of Tcs cells, we used 'transfer in' protocol, where Tcs cells were transferred into recipients that were then EC patched with TNP-Ig prior to TNP-Cl sensitization. To test whether nonconventional $\mathrm{T}$ cells contribute to Tcs cell function, we depleted conventional TCR $\alpha \beta$ cells from ALN cells harvested from animals that were EC treated with TNP-Ig and zymosan. As shown in figure $5 \mathrm{a}$, transfer of non-TCR $\alpha \beta$ $T$ cells abolished the capacity of the countersuppressive function (group D vs. C). To further investigate which subset of $\mathrm{T}$ cells is responsible for the contrasuppressive function, we transferred CD4- or CD8-depleted ALN cells from 'pre-conditioned' mice. Figure $5 \mathrm{~b}$ shows that CD4+ cells are required for contrasuppression (group D vs. C). Thus, data presented in fig. $5 \mathrm{a}$ and fig. $5 \mathrm{~b}$ suggest that the Tcs cells induced via EC immunization with TNP-Ig and zymosan can belong to the population of TCR $\alpha \beta+$ CD4+ lymphocytes. To verify this possibility, another experiment with positively MACS-isolated TCR $\alpha \beta+C D 4+$ cells was performed. As shown in figure $5 c$, the transfer of purified TCR $\alpha \beta+\mathrm{CD} 4+$ Tcs cells prior to the induction of suppression and subsequent TNP-Cl sensitization reversed skin-induced suppression (group D vs. B). In conclusion, the data presented in figure $5 \mathrm{a}-\mathrm{c}$ prove that Tcs cells do indeed belong to the population of TCR $\alpha \beta+$ CD4+ lymphocytes.

\section{Tcs Cells Induced via EC Immunization Are} Antigen-Specific

Our previous study on skin-induced suppression suggested that the suppression is antigen nonspecific. The data shown above suggest that contrasuppression/regulation is antigen-dependent (fig. 4c). To test whether the contrasuppression is also antigen-specific, we performed a new set of experiments, in which we used two different antigens, TNP and OX. In line with our previous study, both TNP-Ig and OX-Ig could induce suppression of TNP-mediated CHS (fig. 6; groups B and D vs. A). However, when mice were EC immunized with OX-Ig and zymosan, this maneuver could not protect TNP-specific CHS from EC induced suppression (fig. 6; group E vs. B).

\section{EC Immunization with TNP-Ig and Zymosan Induces \\ IL-17A Production}

To determine if cytokines are involved in the reversal of skin-induced suppression, we measured the level of two representative Th1 and Th17 cytokines. We found an increase of IFN- $\gamma$ production by ALN cells containing Tcs cells (fig. 7a; group C). It is interesting that there was a robust production of IL-17A by ALN cells containing Tcs cells in the same culture supernatants (fig. $7 \mathrm{~b}$; group C). Our results suggest that IL-17A is most likely involved in the EC/zymosan-induced contrasuppression.

\section{Contrasuppression Induced via EC Immunization with TNP-Ig and Zymosan Is IL-17-Dependent and TLR2- and MyD88-Independent}

To confirm whether Tcs cell function is IL-17A-mediated, we performed a 'transfer out' experiment, using Tcs cells from IL-17A-/-B6 mice. Tcs cell function was completely abolished in the absence of IL-17A (group D vs. C; fig. 8a). It is known that zymosan is a ligand of TLR2 and 


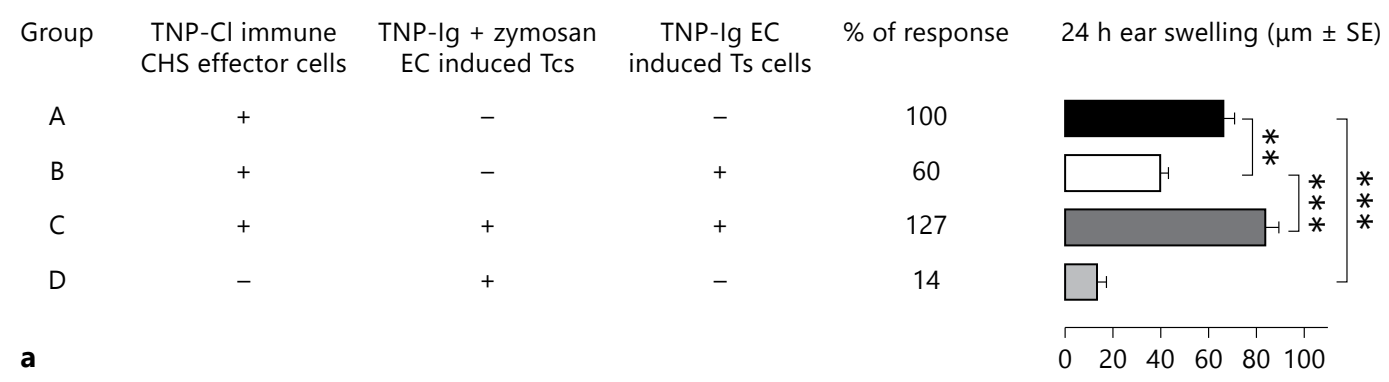

\begin{tabular}{|c|c|c|c|c|c|}
\hline Group & $\begin{array}{l}\text { Cells transferred } \\
\text { from donors EC } \\
\text { treated with }\end{array}$ & $\begin{array}{c}\text { EC immunization } \\
\text { with }\end{array}$ & $\begin{array}{c}\text { TNP-Cl } \\
\text { sensitization }\end{array}$ & $\%$ of response & $24 \mathrm{~h}$ ear swelling $(\mu \mathrm{m} \pm \mathrm{SE})$ \\
\hline A & - & - & + & 100 & +7 \\
\hline B & - & TNP-Ig & + & 54 & $\left.\int \hat{*}_{\rceil}^{*}\right\rceil$ \\
\hline C & - & TNP-lg + zymosan & + & 113 & $\exists \quad \stackrel{*}{*} \underset{*}{*}$ \\
\hline D & TNP-lg & TNP-lg + zymosan & + & 125 & $\left.\mathbb{Z}_{-1}\right]$ \\
\hline E & TNP-Ig + zymosan & TNP-Ig & + & 148 & $\mathbb{W}$ \\
\hline b & & & & & 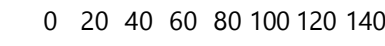 \\
\hline Group & $\begin{array}{l}\text { Cells transferred } \\
\text { from donors EC } \\
\text { treated with }\end{array}$ & $\begin{array}{l}\text { EC immunization } \\
\text { with TNP-Ig }\end{array}$ & $\begin{array}{c}\text { TNP-Cl } \\
\text { sensitization }\end{array}$ & $\%$ of response & $24 \mathrm{~h}$ ear swelling $(\mu \mathrm{m} \pm \mathrm{SE})$ \\
\hline A & - & - & + & 100 & * \\
\hline B & - & + & + & 46 & $\neg$ \\
\hline C & TNP-Ig + zymosan & + & + & 70 & 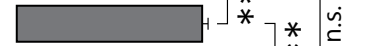 \\
\hline D & zymosan & + & + & 31 & H \\
\hline C & & & & & $0 \quad 50 \quad 100150200250300$ \\
\hline
\end{tabular}

Fig. 4. a Reversal of skin-induced suppression is transferable with ALN cells - 'transfer out' protocol: $7 \times 10^{7}$ of the CHS effector cells from TNP-Cl-sensitized donors were incubated with $5 \times 10^{7}$ ALN cells used as a source of Ts cells isolated from mice (suppression control group B) patched with TNP-Ig. After incubation, the cell mixture was transferred i.v. into naïve recipients (suppression control group B). In addition, $7 \times 10^{7}$ of the $\mathrm{CHS}$ effector cells were incubated with $5 \times 10^{7}$ ALN cells (Tcs cells) from mice EC immunized with TNP-Ig plus zymosan prior to incubation with $5 \times 10^{7}$ lymphoid cells from mice EC immunized with TNP-Ig (Ts cells) (contrasuppression control group $\mathrm{C}$ ). The resultant cells were transferred into naïve recipients. To determine whether ALN cells from mice EC immunized with TNP-Ig and zymosan could transfer CHS, $5 \times 10^{7} \mathrm{ALN}$ cells were transferred i.v. into naïve recipient mice (group D). Recipients were subsequently ear-challenged with TNP-Cl and tested for CHS at $24 \mathrm{~h}$. Results are shown as mean \pm $\mathrm{SE}(\mathrm{n}=12) .{ }^{* *} \mathrm{p} \leq 0.01,{ }^{* * *} \mathrm{p} \leq 0.001$. b Transfer of skin-induced contrasuppression - 'transfer in' protocol. CBA/J mice were EC exposed to PBS (group A), TNP-Ig (group B) or TNP-Ig plus zymosan (group $C$ ). In addition, one group of mice before patching with TNP-Ig plus zymosan received $5 \times 10^{7}$ of EC induced Ts cells (group D) whereas another group of animals was transferred with EC induced Tcs cells before EC immunization with TNP-Ig alone (group E). After patch removal, mice in all the experimental groups were sensitized with TNP-Cl and tested for CHS. Results are shown as mean $\pm \mathrm{SE}(\mathrm{n}=10) .{ }^{* * *} \mathrm{p} \leq 0.001$. c EC immunization with zymosan alone did not reverse skin-induced suppression. CBA/J mice were i.v. transferred with $5 \times 10^{7}$ of ALN cells isolated from donors patched with TNP-Ig plus zymosan (group C) or zymosan alone (group D) and recipient mice were subsequently patched with TNP-Ig. Control groups were EC exposed to PBS (group A) or TNP-Ig (group B) for week. After patch removal, all tested mice were sensitized with TNP-Cl and tested for CHS. Results are shown as mean $\pm \operatorname{SE}(\mathrm{n}=10) .{ }^{* *} \mathrm{p} \leq 0.01,{ }^{* * *} \mathrm{p} \leq 0.001$. n.s. $=$ Non-significant. 


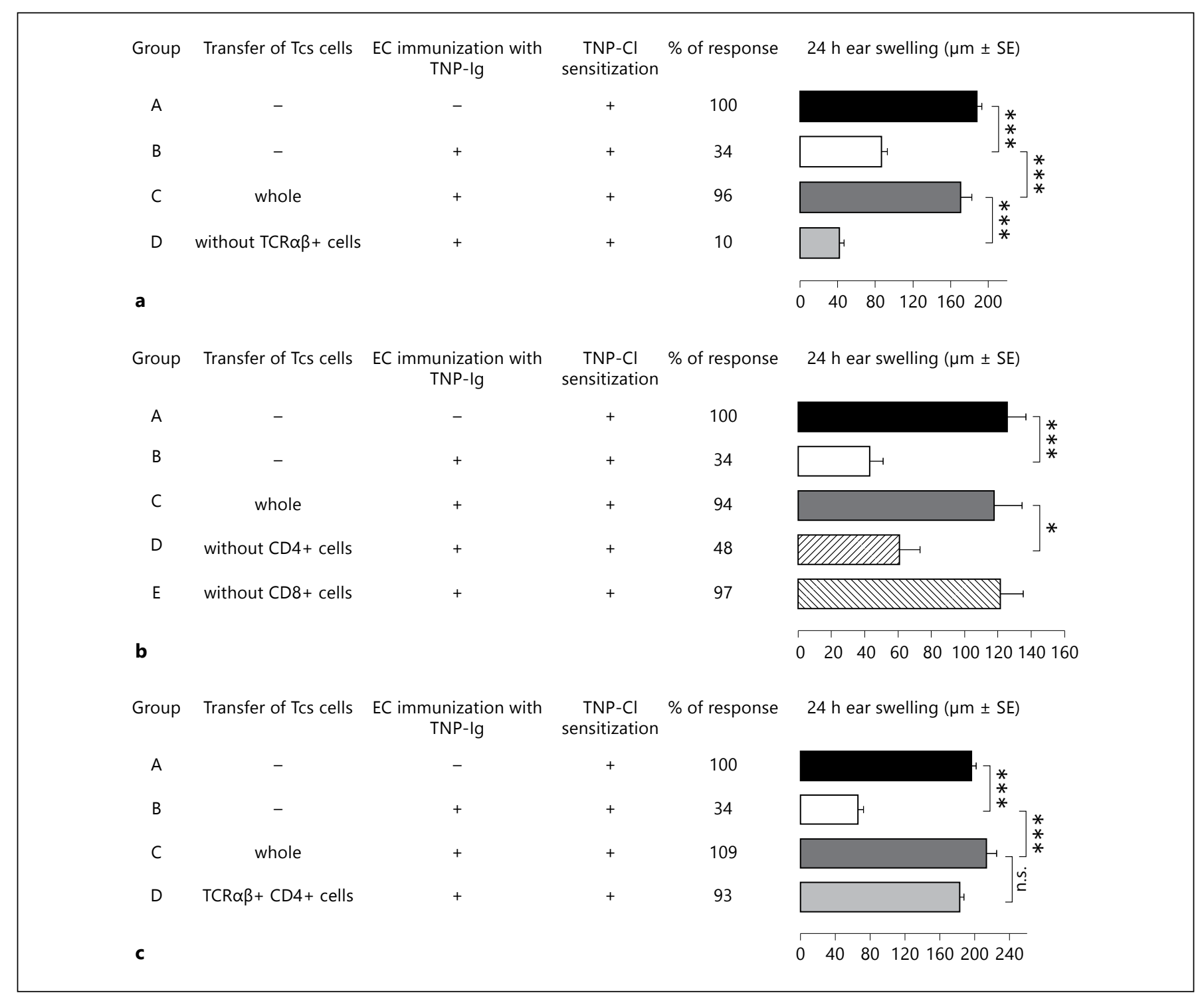

Fig. 5. a TCR $\alpha \beta+$ lymphocytes are involved in skin-induced contrasuppression. ALN cells from animals patched with TNP-Ig plus zymosan were treated with anti-TCR $\beta$ mAb and RC (group D) or $\mathrm{RC}$ alone (group C). Resultant cells were i.v. injected into recipients that were EC immunized with TNP-Ig prior to CHS induction. Animals in control groups were patched with PBS (group A) or TNP-Ig (group B) prior to TNP-Cl sensitization. Four days after sensitization, mice were challenged and tested for CHS. Results are shown as mean $\pm \mathrm{SE}(\mathrm{n}=16)$. $\mathrm{p} \leq 0.001$. $\mathbf{b} \mathrm{CD} 4+$ lymphocytes are required to reverse skin-induced suppression. ALN cells from mice patched with TNP-Ig and zymosan were treated with anti$\mathrm{CD} 4$ or anti-CD8 $\mathrm{mAbs}$ and $\mathrm{RC}$ (groups D and $\mathrm{E}$, respectively). In contrasuppression control, ALN cells were treated with RC alone (group C). Resultant cells were i.v. injected into recipients that were EC immunized with TNP-Ig prior to CHS induction. Control mice were patched with PBS alone (group A) or TNP-Ig (group B) before TNP-Cl painting. The mice were then challenged and tested for CHS. Results are shown as mean \pm SE $(n=10)$. ${ }^{*} \mathrm{p} \leq 0.05$, $* * * \mathrm{p} \leq 0.001$. c Contrasuppressor cells belong to the population of TCRa $\beta+$ CD4+ lymphocytes. ALN cells from donors patched with TNP-Ig and zymosan were used to obtain MACS purified TCR $\alpha \beta+$ CD4+ cells (group D). Contarsuppression control contained whole ALN cells (group C). $5 \times 10^{7}$ ALN cells or $2.1 \times 10^{7}$ MACSpurified TCR $\alpha \beta+C D 4+$ cells were i.v. injected into recipients that were EC immunized with TNP-Ig prior to CHS induction. Mice in control groups were patched with PBS (group A) or TNP-Ig (group B) prior to TNP-Cl sensitization. Four days after sensitization, mice were challenged and tested for CHS. Results are shown as mean \pm SE $(n=14) .{ }^{* * *} \mathrm{p} \leq 0.001$. n.s. $=$ Non-significant. 


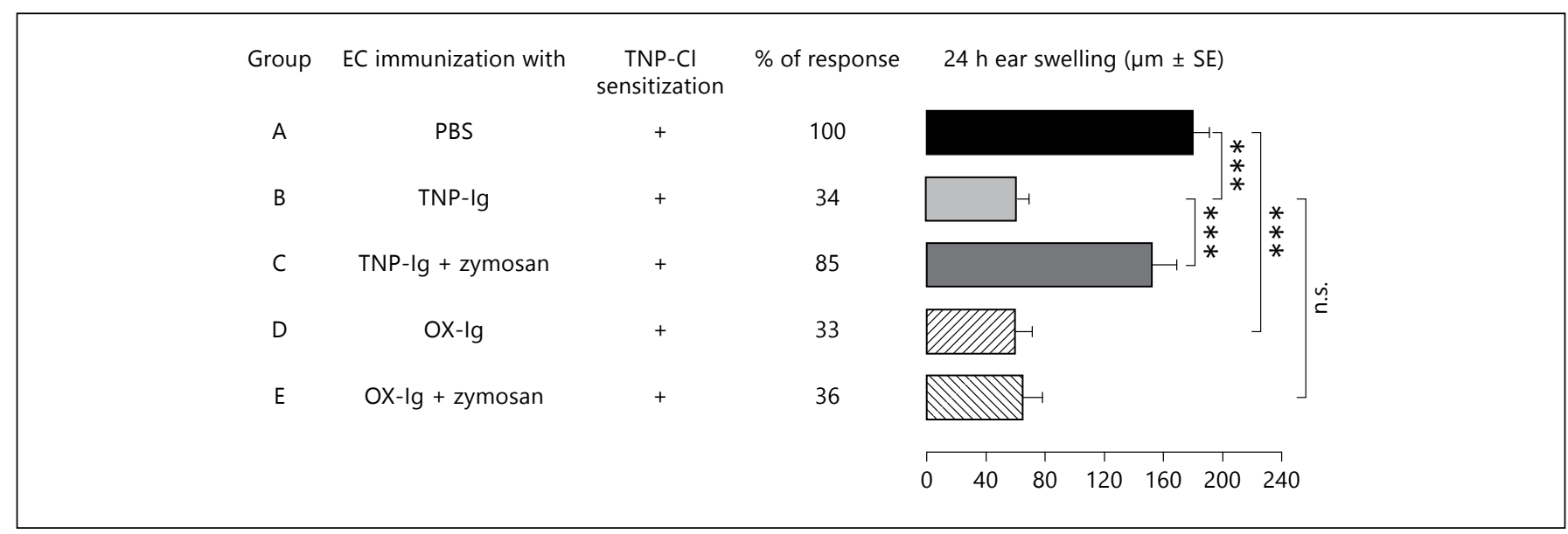

Fig. 6. CBA/J mice were EC immunized with TNP-Ig (group B) or TNP-Ig plus zymosan (group C) or OX-Ig (group D) or OX-Ig plus zymosan (group E) prior to TNP-CL sensitization. The positivecontrol group contained mice patched with PBS and then sensi- tized with TNP-Cl (group A). Four days after TNP-Cl sensitization, animals were tested for CHS. Results are shown as mean $\pm \mathrm{SE}$ $(\mathrm{n}=16) .{ }^{* * *} \mathrm{p} \leq 0.001$. n.s. $=$ Non-significant.

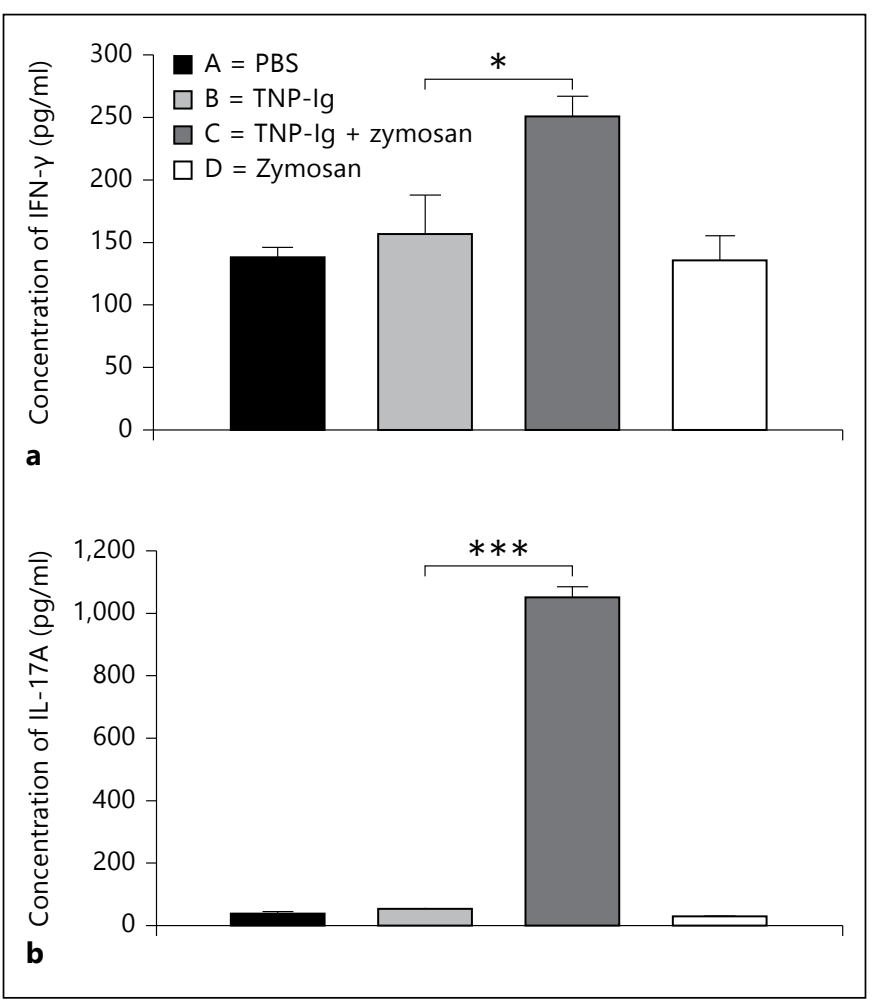

Fig. 7. CBA/J mice were patched with PBS or TNP-Ig or TNP-Ig plus zymosan or zymosan alone (groups $A-D)$. One week later, ALN were collected and then ALN cells $\left(3 \times 10^{6}\right)$ isolated from the tested groups were cultured in the presence of $100 \mu \mathrm{g} / \mathrm{ml} \mathrm{TNP-Ig.}$ After $48 \mathrm{~h}$, supernatants were collected and tested for cytokine concentration. a IFN- $\gamma$ production. Results are shown as mean \pm $\mathrm{SE}(\mathrm{n}=4)$. ${ }^{*} \mathrm{p} \leq 0.05$. b IL-17A production. Results are shown as mean \pm SE $(\mathrm{n}=4){ }^{* * *} \mathrm{p} \leq 0.001$.

EC Induced Contrasuppressor Cells that the TLR2 signaling pathway is MyD88-dependent. To test the role of TLR2 and MyD88, we also transferred Tcs cells from TLR2-/-B6 or MyD88-/-B6 mice. To our surprise, Tcs cell induction and function are not dependent on TLR2 and MyD88 (fig. 8a; groups E and F, respectively). To further confirm our results from 'transfer out' experiments, we tested the active induction of Tcs cells in the knockout mice. As shown in figure $8 \mathrm{~b}$ (group C vs. B), Tcs cells can be induced and fully functional in the absence of TLR2; however, they could not be induced in the absence of IL-17 (fig. 8c; group C). To test whether TLR ligands other than zymosan can induce Tcs cells in the absence of IL-17A, we used LPS (the most abundantly present in the environment and a ligand for TLR4) in the Tcs cell induction. Interestingly, LPS could induce contrasuppression in IL-17A-/- mice (fig. 8c; group D vs. C). Our results suggest that zymosan plays an important role in the induction of Tcs cells that reverse skin-induced suppression, even though TLR signaling does not seem to contribute to the induction of Tcs cells in TLR2-/- mice, nor does it affect IL-17 production (fig. $8 \mathrm{~d}, \mathrm{e}$ ).

\section{Dectin-1 Is Involved in Skin-Induced}

\section{Contrasuppression}

It is known that zymosan generates innate signals, not only via TLR2, but via Dectin-1 as well. Data presented in figure 8 ruled out the involvement of TLR 2 in contrasuppression induced via EC immunization with TNP-Ig and zymosan. These data suggest that receptors other than TLR2 play a role in tested contrasuppression. To verify 
this, animals were EC immunized with TNP-Ig and zymosan or TNP-Ig plus curdlan, which is recognized by Dectin-1. EC immunization with TNP-Ig and curdlan reverses skin-induced suppression similarly to TNP-Ig plus zymosan (group E vs. B and C, respectively; fig. 9a). These in vivo observations were fully confirmed by a proliferation assay in vitro (fig. 9b).

\section{Discussion}

Our previous work showed that EC immunization with a protein antigen prior to hapten sensitization could induce antigen-nonspecific suppression of CHS in mice $[2-5]$. We also found that this antigen-nonspecific inhibition of $\mathrm{T}$ cell-mediated immune response could be reversed by crude bacterial lysates [13] as well by purified TLR ligands [14,21]. Furthermore, experiments with one representative TLR ligand, LPS from E. coli, demonstrated that the observed reversal of skin-induced suppression was antigen-specific, transferable with TCR $\alpha \beta+\mathrm{CD} 4+$ Tcs cells and IL-12- and IFN- $\gamma$-dependent [14].

In this study, we aimed to investigate the mechanism of contrasuppression induced via EC immunization with the protein antigen TNP-Ig and zymosan. We showed that EC immunization with TNP-Ig together with zymosan prior to TNP-Cl sensitization indeed reversed skin-induced suppression as determined by the measurement of ear swelling. This was further confirmed by vascular permeability, ear weight, MPO activity and IL-17A concentration in ear homogenates, and by proliferation assay using ALN cells. In addition, we found that EC immunization with TNP-Ig and zymosan with subsequent ear challenge, but without previous TNP-Cl sensitization, did not lead to a CHS response. This observation was confirmed by an experiment show-

Fig. 8. a Mechanism of skin-induced contrasuppression ('transfer out' protocol). $5 \times 10^{7} \mathrm{ALN}$ cells isolated from control C57Bl/6 (group C) or IL-17A-/-B6 (group D) or TLR2-/-B6 (group E) or MyD88-/-B6 (group F). Mice EC treated with TNP-Ig and zymosan were incubated with $7 \times 10^{7} \mathrm{TNP}$-specific CHS effector cells and then with $5 \times 10^{7} \mathrm{EC}$ induced Ts cells. Positive control recipients were transferred with immune cells alone (group A) whereas the suppression control group received immune cells cotransferred with EC induced Ts cells (group B). The recipients were challenged and tested for CHS. Results are shown as mean $\pm \mathrm{SE}$ $(\mathrm{n}=7) .{ }^{*} \mathrm{p} \leq 0.05,{ }^{* * *} \mathrm{p} \leq 0.001$. b Reversal of skin-induced suppression was TLR2-independent (active immunization protocol). TLR2-/-B6 mice were patched with PBS or TNP-Ig or TNP-Ig plus zymosan (groups A-C), as described in Materials and Meth- ing that injection of ALN cells isolated from donors EC treated with TNP-Ig and zymosan did not transfer the CHS reaction. Our data suggest that EC immunization with the protein antigen and zymosan induces regulatory cells but not CHS effector cells. To test our hypothesis, we employed a 'transfer out' experiment where CHS effector cells were incubated with Tcs cells prior to exposure to Ts cells and subsequent adoptive transfer into naïve recipients. The results showed that $\mathrm{EC} \mathrm{immu-}$ nization with TNP-Ig and zymosan indeed induced cells that protect from skin-induced suppression. Next, using a 'transfer in' protocol, we demonstrated that ALN cells from donors that were EC immunized with TNP-Ig and zymosan blocked EC induced suppression when transferred into recipients just before patching with TNP-Ig alone. Moreover, ALN cells isolated from mice patched with TNP-Ig alone did not affect the induction of contrasuppression when injected just before EC immunization with TNP-Ig and zymosan. In addition, both negative and positive selection experiments show that these EC induced contrasuppressor cells belong to the population of TCR $\alpha \beta+C D 4+$ lymphocytes. This is consistent with our previous finding that the Tcs cells induced via patching with TNP-Ig and LPS were TCR $\alpha \beta+$ CD4+ cells [14].

Zymosan is a preparation of the $S$. cerevisiae cell wall and contains $\beta$-glucan, mannan, mannoprotein and chitin [22]. Zymosan can be recognized by Dectin-1, TLR1, TLR2 and TLR6 [23, 24]. Studies also show that Dectin-2 and NOD2 might play a role in zymosan recognition, as their presence is required for the development of zymosan-induced arthritis $[25,26]$. To test the role of TLR2 in the reversal of skin-induced suppression, we used TLR2-/- mice as a source of contrasuppressor cells. Both the transfer experiment and the active immunization model showed that TLR2 was not required for zymosan-

ods. Seven days later, mice were TNP-Cl-sensitized and then tested for CHS. Results are shown as mean \pm SE $(n=10) .{ }^{* *} \mathrm{p} \leq 0.01$. c Contrasuppression induced via EC immunization with TNP-Ig and zymosan was IL-17A-dependent (active immunization protocol). IL-17A-/-B6 mice were patched with PBS or TNP-Ig or TNPIg plus zymosan or TNP-Ig and LPS (groups A-D), as described in Materials and Methods. Seven days later, mice were sensitized with TNP-Cl and tested for CHS. Results are shown as mean \pm SE ( $\mathrm{n}=$ 8). ${ }^{* *} \mathrm{p} \leq 0.01,{ }^{* * *} \mathrm{p} \leq 0.001$. d, e C57Bl/ 6 or TLR2-/-B6 mice were patched with PBS or TNP-Ig or TNP-Ig plus zymosan (groups A-C). Seven days later, ALN were isolated and ALN cells $\left(3 \times 10^{6}\right)$ were cultured in the presence of $100 \mu \mathrm{g} / \mathrm{ml}$ of TNP-Ig. After $48 \mathrm{~h}$, supernatants were tested for IL-17A concentration. Results shown as mean $\pm \operatorname{SE}(\mathrm{n}=4)$. ${ }^{* * *} \mathrm{p} \leq 0.001$. n.s. = Non-significant.

(For figure see next page.) 
induced contrasuppression. This observation was confirmed in CBA/J wild-type mice, where EC immunization with TNP-Ig and TLR2 ligand Pam3CSK4 did not reverse skin-induced suppression (data not shown). Furthermore, using MyD88-/- mice, we demonstrated that TLR1 and TLR6 were not required for contrasuppression. These observations are in line with published reports that TLR2 and MyD88 play nonessential roles in zymosan-induced arthritis [26]. To test the role of Dectin-1 in skin-induced contrasuppression, mice were EC immunized with TNP-

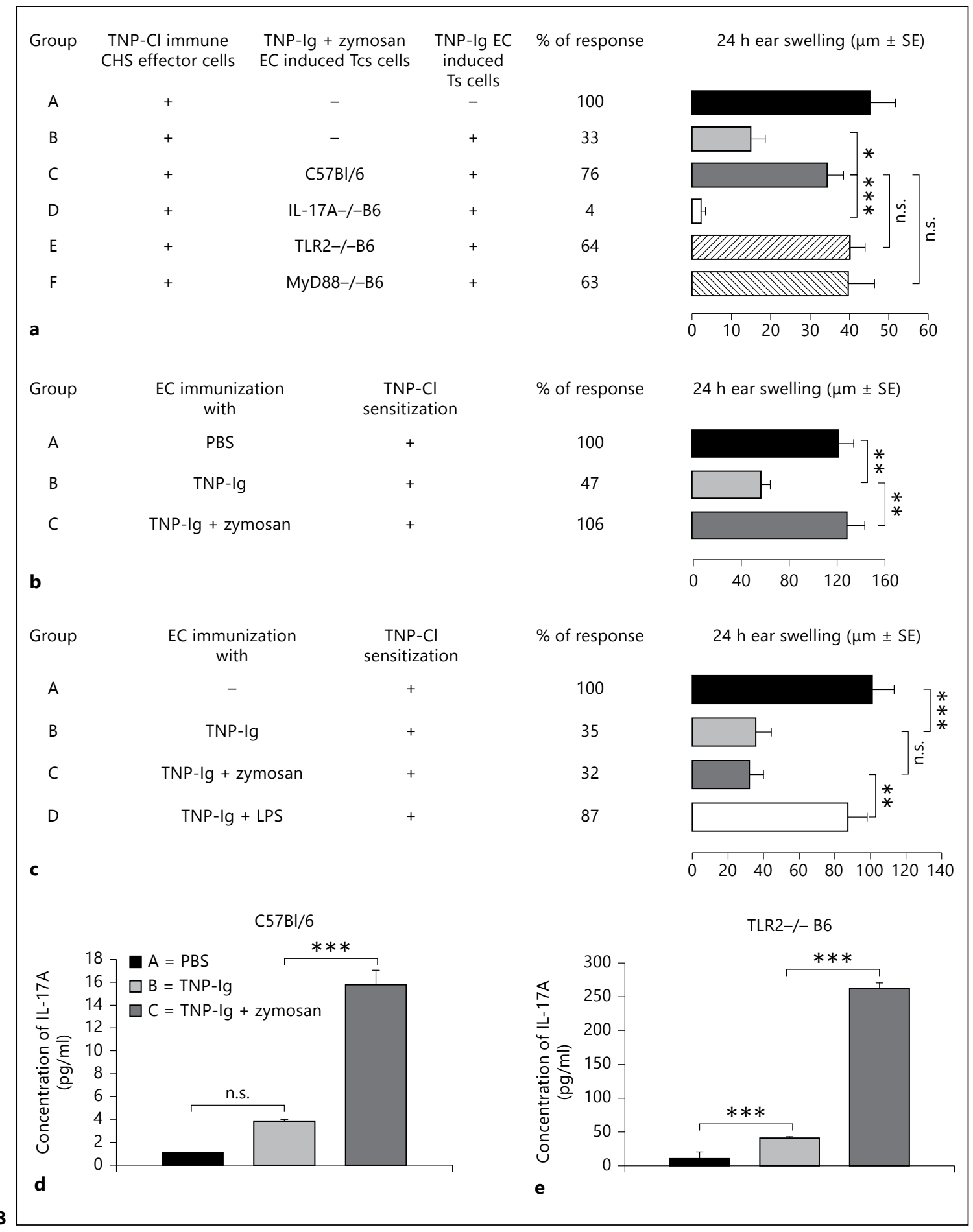




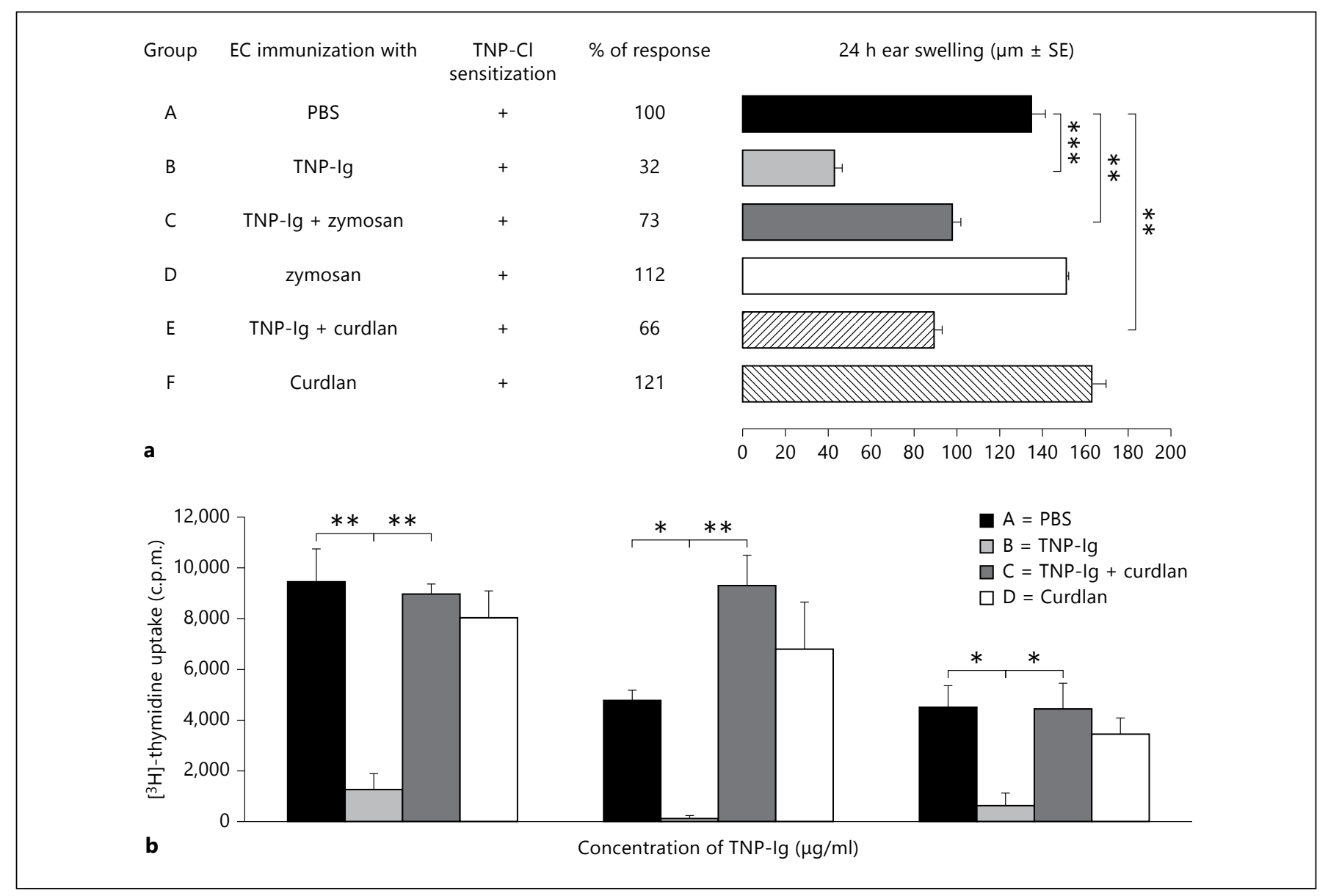

Fig. 9. EC immunization with TNP-Ig and curdlan reversed skininduced suppression. a Reversal of skin-induced suppression in vivo. CBA/J mice were patched with PBS (group A) or TNP-Ig (group B) or TNP-Ig plus zymosan (group C) or zymosan alone (group D) or TNP-Ig plus curdlan (group E) or curdlan alone (group F) prior to TNP-Cl sensitization. Four days later, CHS response was elicited and tested $24 \mathrm{~h}$ later. Results are shown as mean \pm SE $(n=18) .{ }^{* *} \mathrm{p} \leq 0.01,{ }^{* * *} \mathrm{p} \leq 0.001$. b EC immunization with TNP-Ig and curdlan reversed skin-induced suppression in

Ig and curdlan prior to TNP-Cl sensitization. It is known that curdlan is a $\beta$-glucan, a ligand for Dectin- 1 . Both in vivo and in vitro experiments show that when curdlan is applied on the skin together with TNP-Ig, it can reverse skin-induced suppression, similar to the effect induced by EC immunization with zymosan and TNP-Ig. Our data are in line with Ikeda et al. [27], who demonstrate the $\beta$-glucan-dependent characteristics of zymosan.

To test if soluble factors are involved in the reversal of skin-induced suppression, we measured the concentration of proinflammatory cytokines in culture supernatants. We found that EC immunization with TNP-Ig and vitro. CBA/J mice were EC treated with PBS (group A) or TNP-Ig (group B) or TNP-Ig plus curdlan (group C) or curdlan alone (group D) prior to TNP-Cl sensitization. Four days later, ALN cells were isolated and $3 \times 10^{5} \mathrm{ALN}$ cells were cultured in triplicate in the presence of 3-fold dilutions of TNP-Ig for $48 \mathrm{~h}$ and then for an additional $18 \mathrm{~h}$ with $\left[{ }^{3} \mathrm{H}\right]$-thymidine. $\left[{ }^{3} \mathrm{H}\right]$-thymidine incorporation was determined by beta liquid scintillation counting. Results are presented as mean $\pm \operatorname{SE}(\mathrm{n}=3) .{ }^{*} \mathrm{p} \leq 0.05,{ }^{* *} \mathrm{p} \leq 0.01$.

zymosan induced strong production of IL-17A and did not affect the production of IFN- $\gamma$. Both the adoptive transfer experiment and the active immunization of IL$17 \mathrm{~A}-/$ - mice demonstrated that IL-17A plays a crucial role in contrasuppression induced by EC immunization with TNP-Ig and zymosan. The induction of IL-17A in contrasuppression was not TLR2-dependent since ALN cells from TLR2-/- mice patched with TNP-Ig and zymosan produced a similar level of IL-17A in vitro to that in wild-type control C57Bl/6 mice.

It was previously reported that ligation of Dectin-1 and Dectin-2 could trigger the production of pro-Th17 
cytokines and also promotes Th17 responses to fungi [28, 29]. It seems that in our model of contrasuppression, Dectin-1 is involved. Alternatively, Dectin-1 and Dectin-2 may work in concert with innate receptors other than TLR2 or MyD88, e.g. NOD2 [30], to reverse skininduced suppression.

The observation that the transfer of Tcs cells before the induction of suppression overcomes skin-induced suppression may suggest that these contrasuppressor cells play a regulatory function at a very early inductive stage of negative regulation. Moreover, the 'transfer out' experiment proved that EC induced contrasuppressor cells could work in the effector phase of CHS, as they protected CHS effector cells from negative signals released by suppressor cells. These data suggest that Tcs cells interfere with both the induction and effector phases of skininduced suppression.

Lastly, the experiments with two different and noncross-reactive antigens, TNP-Ig and OX-Ig, showed that contrasuppression induced via EC immunization with antigen and zymosan was truly antigen-specific. The induction of Tcs cells required treatment with both antigen and zymosan, as patching with zymosan alone did not result in the reversal of skin-induced suppression. Taken together, our results suggest that EC immunization with antigen and zymosan induces antigen-specific Tcs cells that protect from skin-induced antigen-nonspecific Ts cells. Our study also supports our previous finding that antigen-specific contrasuppression can be induced via EC immunization with antigen and the TLR4 ligand, LPS [14]. However, contrasuppression induced by LPS and zymosan has a different mechanism. As we showed previously, LPS-induced contrasuppression is IL-12- and IFN- $\gamma$-dependent [14] whereas zymosan-induced contrasuppression is mediated by IL-17A. This difference may reflect that LPS and zymosan activate different signaling pathways. LPS is a major ligand for TLR4, which activates both MyD88 and TRIF signaling pathways, which leads to the activation of NF-kB. In our experimental system, zymosan appears to act via Dectin-1. Dectin-1 triggers intracellular signaling via a cytoplasmic ITAM-like motif. Downstream signaling pathways induce a number of innate immune responses including recruitment of Syk, activation of NF- $\kappa B$ via CARD9 and activation of MAPKs and NFAT [31].

In summary, EC immunization with protein antigen TNP-Ig and zymosan induces antigen-specific TCR $\alpha \beta+$ CD4+ Tcs cells that reverse skin-induced suppression. This EC induced contrasuppression is IL-17A-dependent and TLR2- and MyD88-independent.

Our finding suggests that EC immunization with an antigen together with zymosan may play an important role in immunopotentiation and that such maneuvers may be beneficial to enhance the immune response to weakly immunogenic antigens.

\section{Acknowledgements}

This work was supported by grants from the Ministry of Science and Higher Education N N401 545940 and K/ZDS/002182 and National Science Center 2012/05/B/NZ6/00997 to M.S. and JDRF 1-2007-586 to L.W. and NIDDK (RC1DK08769) and DERC to L.W.

\section{References}

1 Askenase PW, Szczepanik M, Itakura A, Kiener C, Campos RA: Extravascular T-cell recruitment requires initiation begun by $\mathrm{Va14+}$ invariant NK T cells and B-1 cells. Trends Immunol 2004;25:441-449.

-2 Szczepanik M, Bryniarski K, Tutaj M, Ptak M, Skrzeczynska J, Askenase PW, Ptak W: Epicutaneous immunization induces $\alpha \beta \mathrm{T}$-cell receptor CD4 CD8 double-positive non-specific suppressor T cells that inhibit contact sensitivity via transforming growth factor- $\beta$. Immunology 2005;115:42-54.

$>3$ Ptak W, Szczepanik M, Bryniarski K, Tutaj M, Ptak M: Epicutaneous application of protein antigens incorporated into cosmetic cream induces antigen-nonspecific unresponsiveness in mice and affects the cell-mediated immune response. Int Arch Allergy Immunol 2002;128:8-14.
4 Majewska-Szczepanik M, Zemelka-Wiącek M, Ptak W, Wen L, Szczepanik M: Epicutaneous immunization with DNP-BSA induces CD4+ CD25+ Treg cells that inhibit Tc1-mediated CS. Immunol Cell Biol 2012;90:784-795.

5 Zemelka-Wiącek M, Majewska-Szczepanik M, Ptak W, Szczepanik M: Epicutaneous immunization with protein antigen induces antigen-non-specific suppression of CD8 T cellmediated contact sensitivity. Pharmacol Rep 2012;64:1485-1496.

6 Majewska-Szczepanik M, Strzępa A, Dorożyńska I, Motyl S, Banach T, Szczepanik M: Epicutaneous immunization with hapten-conjugated protein antigen alleviates contact sensitivity mediated by three different types of effector cells. Pharmacol Rep 2012;64:919-926.

7 Szczepanik M, Tutaj M, Bryniarski K, Dittel $\mathrm{BN}$ : Epicutaneously induced TGF-beta-de- pendent tolerance inhibits experimental autoimmune encephalomyelitis. J Neuroimmunol 2005;164:105-114.

$>8$ Tutaj M, Szczepanik M: Epicutaneous (EC) immunization with myelin basic protein $(\mathrm{MBP})$ induces TCR $\alpha \beta+\mathrm{CD} 4+\mathrm{CD} 8+$ double positive suppressor cells that protect from experimental autoimmune encephalomyelitis (EAE). J Autoimmun 2007;28:208-215.

$\checkmark 9$ Bynoe MS, Evans JT, Viret C, Janeway CA Jr: Epicutaneous immunization with autoantigenic peptides induces T suppressor cells that prevent experimental allergic encephalomyelitis. Immunity 2003;19:317-328.

$>10$ Majewska M, Zając K, Kubera M, Bryniarski K, Ptak M, Basta-Kaim A, Ptak W, Lasoń W, Szczepanik M: Effect of ovoalbumin on the survival of an H-Y incompatible skin graft in C57BL/6 mice. Pharmacol Rep 2006;58:439-442. 
11 Majewska-Szczepanik M, Góralska M, Marcińska K, Zemelka-Wiącek M, Strzępa A, Dorożyńska I, Szczepanik M: Epicutaneous immunization with protein antygen TNP-Ig alleviates TNBS-induced colitis in mice. Pharmacol Rep 2012;64:1497-1504.

12 Strid J, Tan LA, Strobel S, Londei M, Callard R: Epicutaneous immunization with type II collagen inhibits both onset and progression of chronic collagen-induced arthritis. PLoS One 2007;18:e387.

13 Ptak W, Bryniarski K, Ptak M, Majewska M, Gamian A, Lobo FM, Szczepanik M: Toll-like receptor ligands reverse suppression of contact hypersensitivity reactions induced by epicutaneous immunization with protein antigens. Int Arch Allergy Immunol 2006;139: 188-200.

14 Ptak W, Majewska M, Bryniarski K, Ptak M, Lobo FM, Zając K, Askenase PW, Szczepanik M: Epicutaneous immunization with protein antigen in the presence of TLR4 ligand induces TCR $\alpha \beta+\mathrm{CD} 4+\mathrm{T}$ contrasuppressor cells that reverse skin induced suppression of Th1mediated contact sensitivity. J Immunol 2009; 182:837-850.

15 Nakae S, Komiyama Y, Nambu A, Sudo K, Iwase M, Homma I, Sekikawa K, Asano M, Iwakura Y: Antigen-specific T cell sensitization is impaired in IL-17-deficient mice, causing suppression of allergic cellular and humoral responses. Immunity 2002;17:375387.

16 Little JR, Eisen HN: Preparation and characterization of antibodies specific for the 2,4,6-trinitrophenyl group. Biochemistry 1966;5: 3385-3395.
17 McKinney MM, Parkinson A: A simple, nonchromatographic procedure to purify immunoglobulins from serum and ascites fluid. J Immunol Methods 1987;96:271-278.

18 Askenase PW, Asherson GL: Contact sensitivity to oxazolone in the mouse, VIII: demonstration of several classes of antibody in the sera of contact-sensitized and unimmunized mice by a simplified antiglobulin assay. Immunology 1972;27:206-214.

19 Szczepanik M, Lewis J, Geba GP, Ptak W Askenase PW: Positive regulatory gamma delta $\mathrm{T}$ cells in contact sensitivity: augmented responses by in vivo treatment with anti-gamma delta monoclonal antibody, or anti- $\mathrm{V}$ gamma 5 or V delta 4. Immunol Invest 1998; 27:1-15.

20 Zemelka-Wiącek M, Majewska-Szczepanik M, Pyrczak W, Szczepanik M: Complementary methods for contact hypersensitivity (CHS) evaluation in mice. J Immunol Methods 2013;387:270-275.

21 Majewska M, Bryniarski K, Ptak M, Zając K, Zemelka M, Lobo FM, Ptak W, Szczepanik M: Role of TLR ligands in epicutaneously induced suppression. Pharmacol Rep 2009;61: 539-549.

22 Ikeda Y, Adachi Y, Ishii T, Miura N, Tamura H, Ohno N: Dissociation of Toll-like receptor 2-mediated innate immune response to zymosan by organic solvent-treatment without loss of Dectin-1 reactivity. Biol Pharm Bull 2008;31:13-18.

23 Brown GD, Gordon S: Immune recognition. A new receptor for beta-glucans. Nature 2001; 413:36-37.
24 Ozinsky A, Underhill DM, Fontenot JD, Hajjar AM, Smith KD, Wilson CB, Schroeder L, Aderem A: The repertoire for pattern recognition of pathogens by the innate immune system is defined by cooperation between Toll-like receptors. Proc Natl Sci Acad USA 2000;97:13766-13771.

25 DiCarlo EF, Kahn LB: Inflammatory diseases of the bones and joints. Semin Diagn Pathol 2011;28:53-64.

26 Rosenzweig HL, Clowers JS, Nunez G, Rosenbaum JT, Davey MP: Dectin-1 and NOD2 mediate cathepsin activation in zymosan-induced arthritis in mice. Inflamm Res 2011;60: 705-714.

27 Ikeda Y, Adachi Y, Ishii T, Miura N, Tamura $\mathrm{H}$, Ohno N: Dissociation of Toll-like receptor 2-mediated innate immune response to zymosan by organic solvent-treatment without loss of Dectin-1 reactivity. Biol Pharm Bull 2008;31:13-18.

28 Kingeter LM, Lin: C-type lectin receptor-induced NF- $\mathrm{KB}$ activation in innate immune and inflammatory responses. Cell Mol Immunol 2012;9:105-112.

29 Vautier S, Sousa Mda G, Brown GD: C-type lectins, fungi and Th17 responses. Cytokine Growth Factor Rev 2010;21:405-412.

30 Vieira SM, Cunha TM, Franca RF, Pinto LG, Talbot J, Turato WM, Lemos HP, Lima JB, Verri WA Jr, Almeida SC, Ferreira SH, LouzadaJunior P, ZamboniDS, Cunha FQ: Joint NOD2/ RIPK2 signaling regulates IL-17 axis and contributes to the development of experimental arthritis. J Immunol 2012;188:5116-5122.

-31 Kerrigan AM, Brown GD: Syk-coupled Ctype lectins in immunity. Trends Immunol 2011;32:151-156. 